Vol. 7(29), pp. 2154-2157, 3 August, 2013

DOI: $10.5897 / J M P R 11.176$

ISSN 1996-0875 @2013 Academic Journals

http://www.academicjournals.org/JMPR

\title{
Over ground biomass characteristic of medicinal species (Anchusa italica) in northwest Iran (Till area of shabestar)
}

\author{
Hamideh Shadkami ${ }^{1 *}$ and Kamaladin Dilmaghani ${ }^{2}$ \\ ${ }^{1}$ Plant Systematic-Ecology, Department of Plant Biology, Marand Branch, Islamic Azad University, Marand, Iran. \\ ${ }^{2}$ Department of Plant Biology, Marand Branch, Islamic Azad University, Marand, Iran.
}

Accepted 7 October, 2011

\begin{abstract}
Anchusa italica Rezet. is an important medicinal plant belonging to the Boraginaceae Family. It is an herbaceous, perennial and monocarp plant. Flowers appear only once during the life cycle of the plant. Over ground is of medicinal properties. This plant and its products are used in heart strengthening, and eliminating headache and cold. In the research, Anchusa italica biomass was studied in under-over ground plant biomass; vegetal sample was collected from the study area with random plot $1 \mathrm{~m}^{*} \mathrm{~m}$ statistical plant during one of the vegetative seasons in this research. Results of this research showed that plant average root dept is about $13.50 \mathrm{~cm}$, average stem height is about $33 \mathrm{~cm}$ and average over ground of plant biomass is about $0.76 \mathrm{~g} / \mathrm{m}^{2}$ and average over ground of plant biomass is about 3.24 $\mathrm{g} / \mathrm{m}^{2}$.
\end{abstract}

Key words: Anchusa italica, over ground biomass, medicinal, soil.

\section{Introduction}

Anchusa, an important genus of family Boraginaceae, it is distributed in the mountains of tropical Asia and Africa. About 5 species of Anchusa occur in Iran Region (Mozaffarian, 2007). It is reported that harvesting of the whole plant is more destructive than the harvesting of flower, seeds or leaves in isolation. The species is useful in the treatment of headache and cold (Hadjiakhoondi and Baligh, 2002, 2002). The objective of the study was to quantify over-under ground biomass of downy (Anchusa italica Roth.). We define degradation as a decrease in plant species diversity, plant height, vegetation cover and plant productivity. Since measuring root biomass is laborious, few data on this variable are available. Very few studies have used both qualitative and quantitative attributes for assessment of species status (Samant et al., 1996a; Airi et al., 1997, 2000; Bhatt et al., 2005, 2006). In India, Puri et al. (1994) studied the distribution of roots in stands of Populus deltoides.

However, there are good reasons for attempting to northwest Iran, much pasture vegetation was cleared for agricultural land use, consequently ecosystem services obtain more information on root biomass and its relationship to other more easily measurable traits. In provided by rangelands vegetation have been last or seriously changed.

The stabilizing role of rangelands vegetations depend on the increase of shear strength of slopes soil, protection of surface soil, water taken from the soil (via 
Table 1. Collected and determined species with blossom time and geographic height (Ghahraman, 2002, Mozaffarian, 2007).

\begin{tabular}{|c|c|c|c|c|}
\hline \multicolumn{5}{|c|}{ Dicotyledonous: Angiosperms Gamopetalous } \\
\hline Geographic height & Blossoming time & Species Persian name & Species binominal name & Family \\
\hline $\begin{array}{l}\text { Collecting place: } \\
\text { Hussein Abad till, } \\
\text { height } 1500 \mathrm{~m}\end{array}$ & April-June & Gol gavzaban & Anchusa italica & Boraginaceae \\
\hline
\end{tabular}

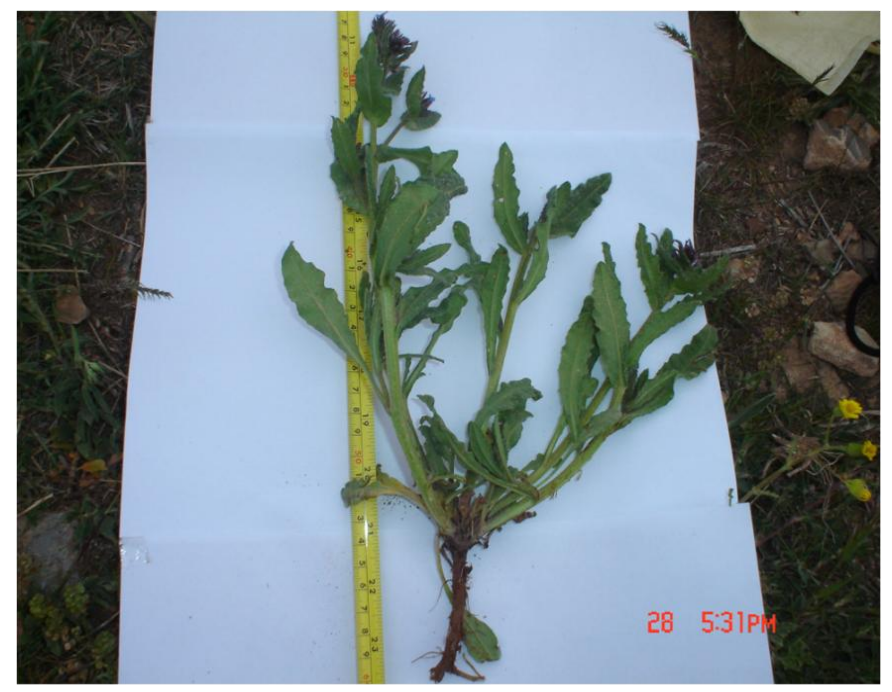

Figure 1. Anchusa italica species.

transpiration and evaporation), increase filtration of soil, support the toe of slope (buttressing), and protecting it from shear failure. These functions can be affected by the rangelands slope scale and slope steepness (Bibalani et al., 2006, 2007). In addition, studies on the relationship between the root biomass of plants and their stem density are needed to improve predictions of the amount of root biomass. The influence of soil type on growth is another important factor that requires further attention (Köestler et al., 1968).

\section{SAMPLING METHODS}

Study area is about $25 \mathrm{~km}$ of Shbestar City between $15^{\prime} 38^{\circ}$ to $38^{\circ}$ $17^{\prime} 30^{\prime \prime}$ North width and $45^{\circ} 27^{\prime} 30^{\prime \prime}$ to $45^{\circ} 30^{\prime}$ East length of prime meridian and the total space of the area is almost $310.31 \mathrm{k} / \mathrm{m}^{2}$, for studying this research, we selected 10 ha space land covered with natural rangeland grasses (Salimi, 2003).

In surface sampling we must have more attention incases such as shape, plat size, design size and the way of writing data. So from sampling the pointed case was determined by surface plat method. Quadrate size $\left(1 \mathrm{~m}^{\star} 1 \mathrm{~m}\right)$ is selected as the best plot. Then sampling was done by the complete accident method after determining the size of optimum plot. Data that were related to soil observation were collected and they generally include erosion information and soil protection. All of the present plants in plots were measured separately in two parts after plant sampling (Shadkami-Til and Bibalani, 2010). Biological spectrum studying of area showed that the more species of type are Hemicriptophyte and Trophite.

A. italica species that grows naturally in Azerbaijan Province of Iran and commonly found in rangelands areas were selected for test. Table 1 shows the Scientific and Farsi name of this species with blossoming time and local position.

\section{RESEARCH METHODS}

For recognition of species for sampling, we used the accidental sampling method. In simple accidental sampling method, everybody was selected equally (Farahvash, 2004). In this sampling, accidental vegetal coverage and/or un-coverage were determined in each plot, after which the geographical direction and elevation determined for each plot.

Sampling is done from early May to late July and it ended late June when $60 \%$ of area coverage was in blossoming stage and most of the plants were used from the previous statistical method in this season. All of the present plants in plots after plant sampling were measured in two parts separately in the study area. After plants were sent to laboratories, each plant was photographed to record the general above- ground and below-ground morphology/architecture prior to being dissected into its component parts to determine biomass. Above-ground biomass was measured by separating the foliage, branches and stem. Each component was oven dried at $80^{\circ} \mathrm{C}$ for $24 \mathrm{~h}$ then weighed. Below-ground biomass was determined by hosing roots clean of soil, before they were oven dried at $80^{\circ} \mathrm{C}$ for $24 \mathrm{~h}$ then weighed. The dry weight of each plant component was recorded to the nearest $0.1 \mathrm{~g}$ and statistical analyzing is done by Excel (Table 2).

\section{RESULTS}

The results showed that in studying area stem height $A$. italica was unsteady from 9 to $23 \mathrm{~mm}$, that in average it is about $16 \mathrm{~mm}$ and the maximum, minimum and medium over ground of biomass in studying area were 4.21, 0.38, $0.28 \mathrm{~g} / \mathrm{m}^{2}$, respectively. The variation in fresh weight during the maturation and senescence phase was significant. Result shows that in studying area $A$. italica biomass over ground and under ground were 4.21 and $0.5 \mathrm{~g} / \mathrm{m}^{2}$ respectively (Figure 1 ).

The values for above ground biomass were, in most cases, higher for senescence phase. During this phase the values varied between 30.94 to $4.21 \mathrm{~g} / \mathrm{m}^{2}$. The comparison of the biomass value at both biomasses over ground and under ground revealed that most of the production $(p<0.5)$ exhibit significantly more values of biomass at over ground (Figure 2). The results showed that $A$. italica depth is $10 \mathrm{~cm}$ and stem height is $16 \mathrm{~cm}$ 
Table 2. Calculation is done for vegetal species.

\begin{tabular}{lcccccc}
\hline Plant binominal name & $\begin{array}{c}\text { Average } \\
\text { height } \mathbf{( c m})\end{array}$ & $\begin{array}{c}\text { Average root } \\
\text { depth }(\mathbf{c m})\end{array}$ & $\begin{array}{c}\text { Total weight } \\
\text { fresh stem }(\mathbf{g})\end{array}$ & $\begin{array}{c}\text { Total weight } \\
\text { fresh root }(\mathbf{g})\end{array}$ & $\begin{array}{c}\text { Total weight } \\
\text { dry stem }(\mathbf{g})\end{array}$ & $\begin{array}{c}\text { Total weight } \\
\text { dry root (g) }\end{array}$ \\
\hline Anchusa italica & & & & & & \\
Average in unit surface & 16 & 10 & 2.10 & 0.18 & 0.28 & 0.05 \\
Maximum & 23 & 11.5 & 30.94 & 1.93 & 4.21 & 0.5 \\
Minimum & 9 & 8.5 & 2.75 & 0.98 & 0.38 & 0.32 \\
\hline
\end{tabular}

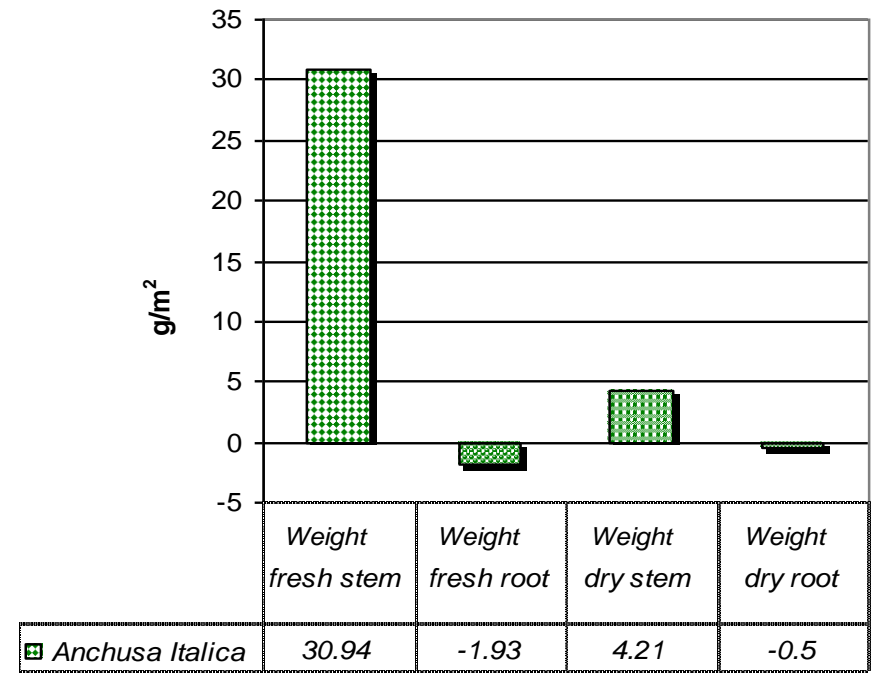

Figure 2. Anchusa italica average biomass over ground and under ground

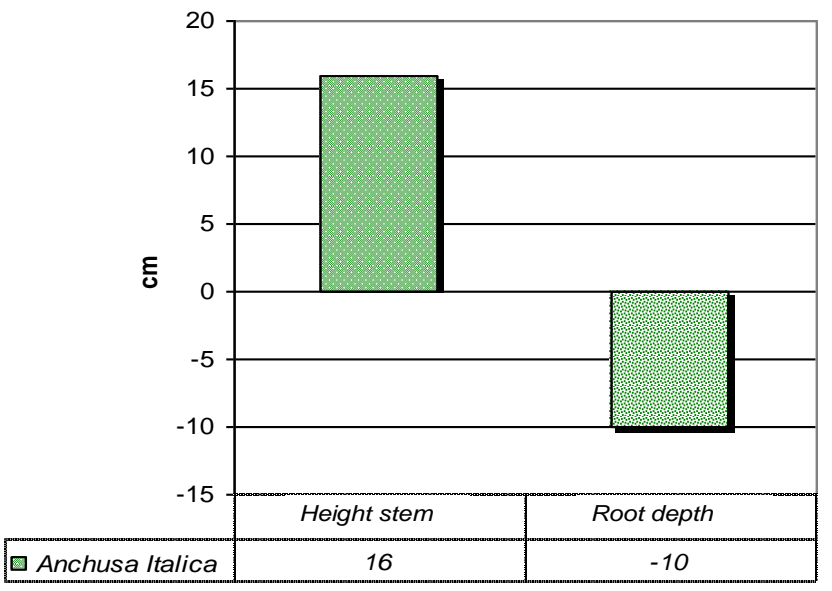

Figure 3. Anchusa italica average root depth and stem height.

(Figure 3).

\section{DISCUSSION}

Studies on quantitative assessment play a vital role in the ecology of the species (Uniyal et al., 2002). It helps in determining the performance of populations under different sets of conditions and provides desired information about the specialized ecological requirements of a taxon (Kaul and Handa, 2001). Due to several adverse factors such as grazing and habitat destruction affecting the growth and survival, the species has become the endangered medicinal plant of northwest Iran.

Over ground biomass is a good indicator of growth, since it is strongly correlated with a number of important physiological parameters, especially photosynthetic activity. The positive relationship between stem biomass and root biomass may indicate the importance of a large stem biomass for producing a high root biomass (Koestler et al., 1968).

The information, thus generated, has immense potential in contributing to the conservation and management of rare threatened plant species (Synge, 1985; Hutchings, 1991). Soil biomass density depends on species, plant age, place and as durable plants increase, soil biomass density will increase (Montagnais et al., 2007). In the case of medicinal plants, time of harvesting is critical because it needs to be related to availability of maximum biomass/ active components. In the present study most of the populations showed significantly more biomass in the senescence phase.

These findings have relevance for sustainable harvesting of the species. In such a situation it is recommended that plants should be harvested in the senescence phase when most of the reproductive stages are completed. The study also recommends the collection of plant material in the senescence phase, which ultimately leads to sustainable utilization of the species.

\section{REFERENCES}

Airi S, Rawal RS, Dhar U, Purohit AN (2000). Assessment of availability and habitat preference of Jatamansi - A critically endangered medicinal plant of west Himalaya. Curr. Sci. 79:1467-1471.

Bhatt A, Joshi SK, Gairola S (2005). Dactylorhiza hatagirea (D. Don) Soo - a west Himalayan orchid in peril. Curr. Sci. 89(1):610-612.

Bhatt A, Rawal RS, Dhar U (2006). Ecological features of a critically rare medicinal plant, Swertia chirayita, in Himalaya. Plant Species Biol. 21(1):49-52.

Bibalani H, Golshani AA, Zahedi SS, Bazrang Z (2007). Soil stabilizing characteristics of Rangelands Vegetation in Northwest Iran Misho Rangelands protected Location of Shabestar, Asian. J. plant Sci. 6(6):1020-1023. 
Bibalani GH, Golshani AA, Zahedi SS, Bazrang Z (2006). Thetration effect of lateral roots of Gavan (Astragalus raddei) on soil reinforcement in Northwest Iran (rangelands of the Shajan area of Shabestar. Can. J. Soil Sci. 86:493-499.

Farahvash F (2004). Ecology, Tabriz: Islamic Azad University Tabriz, pp. 104-116.

Ghahraman A (2002). Folor Colored Iran, Tomes pp.1-24.

Hutchings MJ (1991). Monitoring plant populations: census as an aid to conservation. In: Goldsmith, F.B. (ed.) Monitoring for conservation and ecology. Chapman and Hall, London.

Hadjiakhoondi A, Baligh N (2002). Practical Guidance of medicinal plants, Islamic Azad University Scientific Publication Center, p 35.

Kaul MK, Handa SS (2001). Medicinal plants of crossroads of Western Himalaya. In: Samantl, S.S., Dhar, U. and Palni, L.M.S. (Eds) Himalayan Medicinal Plants: Potential and prospects. Gyanoday Prakashan, Nainital.

Mozaffarian V (2007). A Dicionary of Iranian, Latin, English, Persian. Tehran, Farhang Moaser.

Montagnais A, Magatti G, Scippa G, Chatante D (2007). The roles of root biomass and its depth distribution in mattress pasture on steep slopes(Nardus stricta L.) for soil resistance improvement. Eur. Geosci. Union 61:224-236.
Puri S, Singh V, Bhushan B, Singh S (1994). Biomass production and distribution of roots in three stands of Populus deltoides. For. Ecol. For. Manage. 65:135-147.

Shadkami-Til H, Bibalani Gh (2010). Under-over ground Biomass characterics of perennial Species (Teucruim polium) in northwest Iran (Till area of Shabestar). Int. J. Acad. Res. in press

Salimi FA (2003). Looki To History and Geographical Shabestar, Tasuj, Sufiyan, Tehran Sibe Sorkh. pp. 234-244.

Synge H (1985). The biological aspect of rare plant conservation. Wiley and Sons, Chichester.

Samant SS, Dhar U, Rawal RS (1996a). Natural resource use by natives within Nanda Devi Biosphere Reserve in Western Himalaya. Ethnobotany 8:40-50.

Uniyal SK, Awasthi A, Rawat GS (2002). Current status and distribution of commercially exploited medicinal and aromatic plants in upper Gor Valley, Kumaon Himalaya, and Uttaranchal. Curr. Sci. 82:1246-1252. 